\title{
居住形態からみた女子大生の健康と食生活との意識調査
}

\author{
東川赾美 $* 1 \cdot$ 古崎和代 $* 2 \cdot$ 菊地和美 $* 3 \cdot$ 前田雅子 $* 4 \cdot$ 平井和子 $* 5$ \\ $(* 1$ 藤女子大学, $* 2$ 天使大学, *3酪農学園大学, $* 4$ 畿央大学短期大学部 \\ *5大阪市立大学大学院生活科学研究科)
}

\section{The relation between health and dietary life as seen in living styles among female university students}

\section{Katsumi Higashikawa*1, Kazuyo Furusaki*2, Kazumi Kikuchi*3, Masako Maeda*4, Kazuko Hirai*5}

${ }^{* 1}$ Fuji Women's University, Hanakawa,South 4-5, Ishikari, 061-3204

${ }^{* 2}$ Tenshi College, North-13, East-3, Higashi-ku, Sapporo, 065-0013

${ }^{*}$ Rakuno-Gakuen University 582 Midori-cho, Bunkyo-dai, Ebetsu, 069-8501

${ }^{* 4}$ Kio Collge 4-2-2 Koryo-cho Umami-naka, Kitakatsuragi-gun, Nara Prefecture, 635-0832

${ }^{* 5}$ Graduate School of Human Life Science, Osaka City University, 3-3-138 Sugimoto, Sumiyoshi-ku, Osaka, $558-8585$

*1 $\mathbf{T} 061-3204$ 石狩市花川南 $4-5$

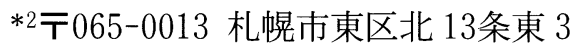

*37069-8501 汇別市文京台緑町 582番地

${ }^{* 4}$ T635-0832 奈良県北葛城郡広陵町馬見中 $4-2-2$

*5 个558-8585 大阪市住吉区杉本 $3-3-138$

A questionnaire survey was conducted among 435 female college students living in Sapporo area, Hokkaido, to study their attitude toward health and dietary life as seen in their living styles.

1 ) A comparison of attitude toward diet at home among three living styles suggested that $97 \%$ of those in their own house and $85 \%$ of students in dormitory consider that they enjoy meal either "little" or "much" or "very much", which indicate that both groups enjoy meal. On the other hand, a higher figure of $24 \%$ of students in boarding houses compared to only $15 \%$ of students in dormitory consider that they are "not enjoying" meal, which confirmed that higher number of students in boarding houses don't enjoy meal (among three living styles $p<0.001$, between their own houses and dormitory $p<0.05$, between their own house and boarding houses $p<$ 0.001).

2 ) Comparatively higher food intake rate was observed in students in their own houses, followed by students in dormitory, and students in boarding houses at the lowest. Compared to students in their own houses, the kind of foods which showed lower food intake rate in students in dormitory were seafood and seaweed, which showed statistical significance (seafood $p<0.001$ and seaweed $p<0.05$ ).

3 ) A higher figure of $54 \%$ of students in boarding houses compared to $32 \%$ of those in their own houses and $43 \%$ of those in dormitory skip meal either "quite often" or "sometimes". On the other hand, a lower figure of $46 \%$ of students in boarding houses compared to $68 \%$ of students in their own houses and $57 \%$ of students in dormitory "do not skip meal", which showed a tendency of higher meal skipping rate in 
〔論文〕 居住形態からみた女子大生の健康と食生活との意識調査

students in boarding houses (among three living styles $p<0.001$, between their own houses and boarding houses $p<0.001$ ).

\section{緒言}

最近は生活様式の多様化を反映して孤食が増えている が，孤食は本来の食事のあり方ではない。石毛11は，人 類の食事文化を特徵づけるものとして，「ヒトは料理を する動物である」，「ヒトは共食する動物である」といっ ている。現実には，1 人で食事をすることは珍しくない が，家族や仲間たちと食べる「共食」がもともとの食事 の形である。厚生省は対象特性別健康づくりのための食 生活指針 2)の中で，食卓を団らんの場として家族とのふ れ合いを図り，食事中の会話による楽しい雾囲気づくり を提示している。

岸田ら ${ }^{3)}$ は，食事中に家族と会話のある方が，生活が より健康的で食生活も優れていることを報告している。

食生活の役割には文化的機能や生理的機能などがあり， 平成12年に厚生省 (現厚生労働省), 文部省（現文部科 学省), 農林水産省から提唱された「食生活指針」から も現代社会において，食生活が重要な位置づけにあるこ とが同える。

昨今，若者の食の乱れが危惧されているが，彼らの食 生活と健康との関連を考察する際に，年毎に变化の度合 いを高める生活環境，とりわけ居住形態の観点から個人 の食生活を捉えていくことが重要になってきた。

しかしながら，これらの調査例は少なく4 8)，特に北 海道における居住形態別からみた女子大生の健康と食生 活に関する報告は，殆ど見られないのが実情である。

そこで本報では，自宅通学生・寮生・下宿生を対象と した調査から，下宿や寮で生活する学生の食生活と健康 との関連に焦点を絞り, 自宅通学生と比較して, 食生活 にどのような問題点があるか，また，その改善が個人レ ベルでどの程度可能であるか，の 2 点を知ることを目的 として調査を実施した。

近年，下宿者を対象として急増したワンルーム・マン ションなどに台所などの水回りが専用に設置されて，住 宅面では，一応，快適な下宿生活環境が作り出されてい る。そこで本調查では，自炊で 1 人住まいをしている学 生を下宿生とし， 2 食付で学生会館の居住者を寮生とし， 自宅通学生を自宅生として，これら３群の食生活と健康 に関する意識調査を行い, 若干の知見を得たので報告す る。

\section{方 法}

\section{1. 調査対象}

調査対象は, 札幌市とその近郊に在住する人間生活学

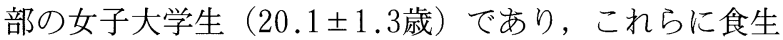
活意識調査, 生活行動調查を実施して, 有効回答数 435 人，有効回答率 $100 \%$ を得た。対象者の内訳は，自宅通
学生 251 人 $(57.7 \%)$, 下宿生 131 人 $(30.1 \%)$, 寮生 53 人 (12.2\%) である。

\section{2. 調 査}

2002年 6 月下旬〜 7 月上旬に実施した。

\section{3 . 調査内容}

調査内容は，3つの居住形態からみた学生の健康に関 わる食行動への意識に関連するもの（ 9 項目）, 健康に 関わる保健行動 ( 6 項目), 健康と心的状態への認識関 連 (5 項目), 食品の摂取頻度関連 (13項目) およびサ プリメント関連（4項目）であった。

調査に際しては，自記式のアンケート調査用紙を配布。 各調査項目に対して $\chi^{2}$ 検定を用いて検討し, 有意水準 は $5 \%$ 以下とした。

また居住形態と食品摂取頻度に関する項目の関係をみ るため, 多変量解析である因子分析も試み, 集計結果の 解析は, エクセル統計 2000 を用いた。次の11食品（豆類, 魚介類, 卵類, 肉類, 植物油, 緑黄色野菜, 淡色野菜, 果物類, 乳類, 海藻, 菓子類) を説明変数として, 相互 の関連性や類似性を明らかにするため，因子分析を行っ た。

\section{結果および考察}

\section{1. 居住形態と食行動および食生活意識との関連性}

（1）健康に関わる食行動の比較 調査項目として, 食生活意識については “食生活に気をつけているか”と “健康に適した食生活をしていると思うか”，“必要な栄 養素を食事から摂れていると思うか”の 3 項目, 食行動 については, “欠食”. “偏食”の有無, “甘くて塩味の濃 いものを好むか”, “食事前後の挨拶” “食事速度”, “家 族上の共食状況”の 6 項目を，それぞれ回答してもらい， その結果を表 1 に示した。表 1 は各項目に対する人数 （\%）で表し，それぞれの居住形態別（縦）の合計が100 \%になるように示した。

食生活意識については，“食生活に気をつけている” と答えたものは自宅生 $35 \%$, 寮生 $49 \%$, 下宿生 $43 \%$ で, “あまり気をつけていない”が自宅生 $21 \%$, 寮生 $15 \%$, 下宿生 $23 \%$ で有意差はみられなかったが，寮生は食生活 に気を付けている傾向がみられた。

健康と食生活に関する意識については，“健康を保つ のに適した食生活”を“している”と“大体している” を合わせた合計は，自宅生と寮生が各々 $46 \%$ と最も多く， 下宿生は $28 \%$ であった。健康な食生活を“していない” は自宅生 $20 \%$, 寮生 $25 \%$ に対して，下宿生は $44 \%$ と多く， 3 居住間に有意な差がみられ，健康に適した食生活への 意識が自宅生と寮生で高かった（3 居住間 $p<0.001$, 自宅と下宿間 $p<0.001$ ，寮と下宿間 $p<0.001) 。$ 必要な栄養素を食事から拱れているかについては“十 
表 1 健康に関わる食行動の比較

人 $(\%)$

\begin{tabular}{|c|c|c|c|c|}
\hline \multirow{2}{*}{ 調 査 項 目 } & \multicolumn{3}{|c|}{ 居 住 形 態 } & \multirow{2}{*}{$\begin{array}{c}3 \text { 居住間の } \\
\text { (関連性 } \\
\chi^{2} \text { 検定 }\end{array}$} \\
\hline & 自 宅 & 寮 & 下＼cjkstart宿 & \\
\hline \multicolumn{5}{|l|}{ 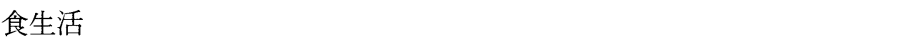 } \\
\hline 気をつけている & $86(35.1)$ & $26(49.1)$ & $56(43.4)$ & \multirow{3}{*}{ ns } \\
\hline 変わらない & $108(44.1)$ & $19(35.8)$ & $43(33.3)$ & \\
\hline あまり気をつけていない & $51(20.8)$ & $8(15.1)$ & $30(23.3)$ & \\
\hline \multicolumn{5}{|l|}{ 健康に適した食生活 } \\
\hline している & $15(6.0)$ & $6(11.5)$ & $0(0.0)$ & \multirow{5}{*}{$p<0.001$} \\
\hline 大体している & $100(40.0)$ & $18(34.6)$ & $36(27.5)$ & \\
\hline どちらともいえない & $84(33.6)$ & $15(28.8)$ & $36(27.5)$ & \\
\hline していない & $50(20.0)$ & $13(25.0)$ & $58(44.3)$ & \\
\hline わからない & $1(0.4)$ & $0(0.0)$ & $1(0.8)$ & \\
\hline \multicolumn{5}{|l|}{ 必要な栄養素 } \\
\hline 十分摂れている & $36(14.3)$ & $7(13.2)$ & $2(1.5)$ & \multirow{3}{*}{$p<0.001$} \\
\hline 大体摂れている & $152(60.6)$ & $31(58.5)$ & $55(42.0)$ & \\
\hline 摂れていない & $63(25.1)$ & $15(28.3)$ & $74(56.5)$ & \\
\hline \multicolumn{5}{|l|}{ 欠食状況 } \\
\hline 欠食しない & $169(67.6)$ & $30(56.6)$ & $60(45.8)$ & \multirow{3}{*}{$p<0.001$} \\
\hline 時々欠食する & $66(26.4)$ & $16(30.2)$ & $53(40.5)$ & \\
\hline よく欠食する & $15(6.0)$ & $7(13.2)$ & $18(13.7)$ & \\
\hline \multicolumn{5}{|l|}{ 偏食 ～～～～～～～～～} \\
\hline 偏食はない & $153(61.9)$ & $33(63.5)$ & $73(59.8)$ & \multirow[t]{2}{*}{ ns } \\
\hline 偏食をしている & $94(38.1)$ & $19(36.5)$ & $49(40.2)$ & \\
\hline \multicolumn{5}{|l|}{ 甘くて塩味の濃いもの } \\
\hline 好き & $63(25.3)$ & $17(32.1)$ & $39(29.8)$ & \multirow{3}{*}{$\mathrm{ns}$} \\
\hline 普通 & $134(53.8)$ & $29(54.7)$ & $74(56.5)$ & \\
\hline 嫌い & $52(20.9)$ & $7(13.2)$ & $18(13.7)$ & \\
\hline \multicolumn{5}{|l|}{ いただきます・ごちそうさま } \\
\hline 全然言わない & $15(6.0)$ & $2(3.8)$ & $21(16.2)$ & \multirow{4}{*}{$p<0.01$} \\
\hline 時々言う & $97(38.8)$ & $25(47.2)$ & $56(43.1)$ & \\
\hline いつも言う & $102(40.8)$ & $14(26.4)$ & $42(32.3)$ & \\
\hline 絶対に忘れない & $36(14.4)$ & $12(22.6)$ & $11(8.5)$ & \\
\hline \multicolumn{5}{|l|}{ よくかんでゆっくり } \\
\hline 非常に早食い & $15(6.0)$ & $6(11.3)$ & $11(8.4)$ & \multirow{5}{*}{ ns } \\
\hline やや早い & $92(36.8)$ & $20(37.7)$ & $53(40.5)$ & \\
\hline 普通 & $91(36.4)$ & $21(39.6)$ & $43(32.8)$ & \\
\hline 遅い & $46(18.4)$ & $6(11.3)$ & $19(14.5)$ & \\
\hline 非常に遅い & $6(2.4)$ & $0(0.0)$ & $5(3.8)$ & \\
\hline \multicolumn{5}{|l|}{ 食事は家族と } \\
\hline いつも一緒ではない & $37(14.9)$ & $20(46.5)$ & $111(91.7)$ & \multirow{3}{*}{$p<0.001$} \\
\hline 時々一緒 & $128(51.4)$ & $23(53.5)$ & $10(8.3)$ & \\
\hline ほとんど一緒 & $84(33.7)$ & $8(0.0)$ & $0(0.0)$ & \\
\hline
\end{tabular}

学生の欠食状況は“よく欠食する”と “時々欠食する”を合わせた合計が，自 宅生 $32 \%$, 寮生 $43 \%$, 下宿生 $54 \%$ と多く, “欠食しない” は自宅生 $68 \%$, 寮生 $57 \%$, 下宿生 $46 \%$ と少なく, 下宿生で欠食頻度 が最も高い傾向がみられた（3 居住間 $p$ $<0.001$, 自宅と下宿間 $p<0.001)$ 。

欠食状況を, 平成 13 年国民栄養調査 ${ }^{10)}$ の同年代值と比べると, 後者の “ほとん ど毎日欠食する”抢よび “週 $2 \sim 5$ 回欠 食”の合計は，20２9歳が35\%であり， 欠食習慣のあるものは国民栄養調查値よ り本調查值の方が, 自宅生 $3 \%$, 寮生 8 \%, 下宿生 $19 \%$ と高かった。既に報告 9 ) した大阪の女子大学生の調査と比較する と“よく久食する” “時々欠食する” 合 わせた合計（44\%）と比べて自宅生 $12 \%$, 寮生 $1 \%$ 低く, 下宿生は $10 \%$ 高く, 特に 下宿生にそれが顕著であった。

学生の偏食について, “偏食はない” は自宅生 $62 \%$, 寮生 $64 \%$, 下宿生 $60 \%$ で “偏食をしている”は自宅生 $38 \%$, 寮生 $37 \%$, 下宿生 $40 \%$ で学生の約 4 割が偏食 をしていた。

“甘くて塩味の濃いものを好むか”に ついて, “好き”は自宅生 $25 \%$, 寮生 32 $\%$, 下宿生 $30 \%$ で，“嫌い”は自宅生 21 $\%$, 寮生 $13 \%$, 下宿生 $14 \%$ で, 学生は濃 い味を好む傾向がみられた。

食事前後の挨拶「いただきます・ごち そうさま」を“絶対に忘れない”, “いつ も言う”を合わせた合計は, 自宅生 $55 \%$, 寮生 $49 \%$ に対して, 下宿生は $41 \%$ と少な く, “全然言わない”, “時々言う”を合 わせた合計は自宅生 $45 \%$, 寮生 $51 \%$, 下 宿生 $59 \%$ で，食事前後の挨拶をしないも のは下宿生に多かった（ 3 居住間 $p<$ 0.01 , 自宅と下宿間 $p<0.01$, 寮と下宿 間 $p<0.05)$ 。

食事速度については, “非常に早い”, “やや早い”合わせた合計は, 自宅生 43 $\%$, 寮生, 下宿生各々 $49 \%$ で, “非常に 遅い”, “遅い”合わせた合計は自宅生 21 $\%$, 寮生 $11 \%$ ，下宿生は $18 \%$ で食事速度

分摂れている”と“大体撕れている”と答えた合計は, 自宅生 $75 \%$, 寮生 $72 \%$ と多く, 下宿生は $44 \%$ と少なか力 た。“摂れていない”と答えたものは, 自宅生 $25 \%$, 寮 生 $28 \%$ で，下宿生は $57 \%$ と多く有意差がみられた（3 居 住間 $p<0.001$, 自宅と下宿間 $p<0.001$, 寮と下宿間 $p$ $<0.001$ )。
は速い傾向がみられた。

共食状況では，家族と“ほとんど一緒”に食べている と, “時々一緒”を合わせた合計は, 自宅生 $85 \%$, 寮生 $54 \%$, 下宿生 $8 \%$ と少なく, “いつも一緒でない”は, 自宅生 $15 \%$, 寮生 $47 \%$, 下宿生 $92 \%$ と多く有意差が反ら れた（3 居住間 $p<0.001$, 自宅と寮間 $p<0.001$, 自宅 
〔論文〕居住形態からみた女子大生の健康と食生活との意識調査

と下宿間 $p<0.001$, 寮と下宿間 $p<0.001)$ 。下宿生と寮 生は，自宅外通学生であるが，寮生は同世代と，また時 々家族と一緒に共食することが多く，下宿生はほとんど が 1 人暮らしで “孤食”するものが多かった。

下宿における孤食や食事リズムの乱れによる偏食・次 食の増加, 誤った情報の影響を受けた食事のアンバラン スなどは, 精神的・身体的に不調和を来たす人の増加な どのひずみ現象を引き起こすと言われている11a)。健康 な生活を営むためには，家族や仲間たちと食べる「共食」 や望ましい食行動の習慣化が重要と思われる。

（2）健康に関わる保健行動の比較健康に関する意 識について, “排便回数”, “体を動かす時間”, “睡眠状 況”, “朝の目覚め” “瘦せ願望”, “今後の体調” の 6 項 目について，その状態を調べた（表 2 ）。

排便回数をみると, 排便が週に 3 回以下の “便秘傾向” の割合は，自宅生 $21 \%$ ，寮生 $16 \%$ に対して，下宿生 $28 \%$

表 2 健康に関わる保健行動の比較

\begin{tabular}{|c|c|c|c|c|}
\hline \multirow{2}{*}{ 調 査 項 目 } & \multicolumn{3}{|c|}{ 居 住 形 態 } & \multirow{2}{*}{$\begin{array}{c}3 \text { 居住間の } \\
\text { 関連性 } \\
\left(\chi^{2} \text { 検定 }\right)\end{array}$} \\
\hline & 自 宅 & 寮 & 下 宿 & \\
\hline \multicolumn{5}{|l|}{ 排便回数 } \\
\hline 3 回以下/週 & $53(21.4)$ & $8(15.7)$ & $37(28.2)$ & \multirow{4}{*}{ ns } \\
\hline $4 \sim 6$ 回/週 & $98(39.5)$ & $24(47.1)$ & $53(40.5)$ & \\
\hline 7 回以上/週 & $52(21.0)$ & $11(21.6)$ & $22(16.8)$ & \\
\hline 不規則 & $45(18.1)$ & $8(15.7)$ & $19(14.5)$ & \\
\hline \multicolumn{5}{|l|}{ 運動·通勤·仕事·家事 } \\
\hline 8 時間以上/日 & $19(7.6)$ & $2(3.8)$ & $8(6.1)$ & \multirow{5}{*}{ ns } \\
\hline $5 \sim 7$ 時間/日 & $53(21.3)$ & $7(13.2)$ & $25(19.1)$ & \\
\hline $3 \sim 4$ 時間/日 & $83(33.3)$ & $27(50.9)$ & $45(34.4)$ & \\
\hline $1 \sim 2$ 時間/日 & $77(30.9)$ & $14(26.4)$ & $42(32.1)$ & \\
\hline ほとんど何もしていない & $17(6.8)$ & $3(5.7)$ & $11(8.4)$ & \\
\hline \multicolumn{5}{|l|}{ 睡 眠 } \\
\hline ぐっすり眠れない & $14(5.6)$ & $5(9.4)$ & $15(11.5)$ & \multirow[t]{4}{*}{ ns } \\
\hline 時々眠れない & $65(26.1)$ & $14(26.4)$ & $42(32.1)$ & \\
\hline よく眠れる & $109(43.8)$ & $18(34.0)$ & $55(42.0)$ & \\
\hline 非常によく眠れる & $61(24.5)$ & $16(30.2)$ & $19(14.5)$ & \\
\hline \multicolumn{5}{|l|}{ 朝の目覚めは } \\
\hline 非常に起きにくい & $72(28.8)$ & $21(39.6)$ & $42(32.1)$ & \multirow{4}{*}{ ns } \\
\hline 時々起きにくい & $116(46.4)$ & $20(37.7)$ & $58(44.3)$ & \\
\hline 普通 & $44(17.6)$ & $9(17.0)$ & $20(15.3)$ & \\
\hline 爽やかに目覚める & $18(7.2)$ & $3(5.7)$ & $11(8.4)$ & \\
\hline \multicolumn{5}{|l|}{ 瘦せ願望 } \\
\hline 非常に瘦せたい & $103(41.4)$ & $25(47.2)$ & $69(52.7)$ & \multirow{4}{*}{ ns } \\
\hline 少し瘦せたい & $104(41.8)$ & $20(37.7)$ & $49(37.4)$ & \\
\hline あまり感じない & $35(14.1)$ & $5(9.4)$ & $9(6.9)$ & \\
\hline 全然感じない & $7(2.8)$ & $3(5.7)$ & $4(3.1)$ & \\
\hline \multicolumn{5}{|l|}{ 今後の体調 } \\
\hline 病気にならず, 元気 & $154(64.7)$ & $24(47.1)$ & $53(44.9)$ & \multirow{3}{*}{$p<0.01$} \\
\hline 栄養指導を希望 & $52(21.8)$ & $13(25.5)$ & $32(27.1)$ & \\
\hline 不安 & $32(13.4)$ & $14(27.5)$ & $33(28.0)$ & \\
\hline
\end{tabular}

人 $(\%)$

と多く, 逆に毎日排便のあるものは，自宅生 $21 \%$, 寮生 $22 \%$ ，下宿生 $17 \%$ と少ない傾向がみられた。

1 日に体を動かす時間をみると, “ $3 \sim 4$ 時間” が最 も多く自宅生 $33 \%$, 寮生 $51 \%$, 下宿生 $34 \%$ であり，次い で“ 1 〜 時間”であった。

睡眠の熟眠程度について, “よく眠れる”, “非常によ く眠れる”と答えた合計は自宅生 $68 \%$, 寮生 $64 \%$, 下宿 生 $57 \%$ と多く，逆に“ぐっすり眠れない”，“時々眠れな い”は自宅生 $32 \%$, 寮生 $36 \%$, 下宿生 $44 \%$ と自宅生に比 べ下宿生に睡眠不足を感じているものが多かった（自宅 と下宿間 $p<0.05)$ 。休養 ·こころの健康づくりの一つ には, 十分な睡眠の確保があげられる。睡眠不足は, 疲 労感や情緒不安定, 適切な判断力の低下など, 生活の質 に大きな影響を与える重要な問題である11b)。我が国で は，成人の $23.1 \%{ }^{11 b)}$ に睡眠に関連した健康問題がある といわれているが，本調査ではそれを自宅生 $9 \%$, 寮生 13\%，下宿生 $21 \%$ も上回っており，睡眠 が十分とれるような休養・こころの健康 が必要であることを示唆している。

朝の目覚めについて, “非常に起きに くい”という回答は, 自宅生 $(29 \%)$ よ り寮生（40\%)，下宿生（32\%）に多い 傾向がみられ，爽やかに目覚める割合は， 自宅生 $(7 \%)$, 寮生 $(6 \%)$, 下宿生 （８\%）とほぼ同值であった。既に報告 した ${ }^{12)}$ 学生の欠食と朝の目覚めの関連性 では, よく欠食する学生に朝 “非常に起 きにくい”との回答が高く差異がみられ たことから, 欠食のひとつの理由は, 朝 寝坊によるものと思われる。

瘦せ願望については 3 居住間に有意な 関連性はみられなかったが “非常に瘦せ たい”，“少し瘦せたい”と答えた合計が， 自宅生 $83 \%$, 寮生 $85 \%$, 下宿生 $90 \%$ と多 く“あまり感じない”が自宅生 $14 \%$, 寮 生 $9 \%$, 下宿生 $7 \%$ と少なく, 自宅生よ り下宿生に瘦せ願望が強い傾向がみられ た。瘦せ願望について, 平成 10 年国民栄 養調査 ${ }^{11)}$ の同年代值と比べると, 本調査 值の“非常に瘦せたい”が自宅生 $41 \%$, 寮生 $47 \%$, 下宿生 $53 \%$ となり, 後者の “太っている” と意識する者が20～29歳 では $45 \%$ であり，学生のやせ志向は，国 民栄養調査值より自宅生は $4 \%$ 低く, 寮 生は $2 \%$, 下宿生は $8 \%$ 高かった。これ らのことから, 特に自宅外通学生の欠食 率が高かった理由は, 時間の都合（朝寝 坊をして食欲がない，食べたくない）と 太りたくないためと考えられる。さらに 2002年度自宅外通学生の生活費（仕送り 
額から家賃を引いた月平均額） ${ }^{13)}$ は過去 最低（札幌圏約 4 万円 - 首都圏 5 万 2 千 円）であり，不景気で仕送りが減る一方 で, 生活費を切り詰めている実態があり, これらが欠食に拍車を掛け，その頻度が 高くなったものと推察される。

今後の体の調子について, “病気にな らずに元気である”と回答したものの割 合は, 自宅生 $65 \%$ が最も高く, 寮生 $47 \%$, 下宿生 $45 \%$ と低かった。体調 “不安”を 意識する割合は, 自宅生 $13 \%$ と低く, 寮 生・下宿生は各々 $28 \%$ と自宅生の約 2 倍 であり, “病気にならないように栄養指 導してほしい”は，それぞれ $22 \% ， 26 \% ，$ $27 \%$ であった（3 居住間 $p<0.01$, 自宅 と寮間 $p<0.05$, 自宅と下宿間 $p<0.01)$ 。 寮生と下宿生の半数以上が体調不安を意 識し，栄養指導を希望していた。

以上のことから, 下宿生は自宅生に比 べて，健康に適した食生活をする意識が 低く，偏食や欠食するものが高く，今後 の体調が不安であり, 指導してほしいと 感じていることが示唆された。

しかし, 明確な自覚症状がないことも あり, 自宅生に比べて, 下宿生が健康に 配慮した生活を心がけることは難しいと いえる。だが，欠食などによる貧血や生 活習慣病の予防上，現状のままの生活を 続ける限り，健康への影響が深刻になる ことは十分に予測される。従って，自覚 症状のないものに, いかに行動変容をさ せるかが，今後の重要な課題になると思 われる。栄養教育と正しい食習慣への生活改善が望まれ る。

（3）健康に関わる心的状態の比較 調査項目として “家での食事”, “学校での気分”, “家での気分”, “毎日 の気分”, “現在の健康状態 “の 5 項目について設問した (表 3 )。

家での食事について居住形態別に比較すると, “少し 楽しい”, “楽しい”“非常に楽しい”を合わせると, 自 宅生 $(97 \%)$ と寮生（85\%）に食事を楽しむ傾向があり， 逆に“楽しんでいない” は, 寮生 $(15 \%)$ より下宿生 (24\%) に多いことが認められた（3居住間 $p<0.001$, 自宅と寮間 $p<0.05$, 自宅と下宿間 $p<0.001)$ 。食事の 場11c) とは, 単に食事を共にするだけでなく, 豊かなコ ミュニケーションを創造する場でもある。食事を共有す る・食事を共にするということ自体, 優れて親しさの度 合いを高める無言のコミュニケーションの役割を果たし ている。ところで, 下宿生は孤食であるために, この役 割を享受することができず, 摂取食品数も限られて, 食
表 3 健康に関わる心的状態の比較

人 $(\%)$

\begin{tabular}{|c|c|c|c|c|}
\hline \multirow{2}{*}{ 調 査 項 目 } & \multicolumn{3}{|c|}{ 居 住 形 態 } & \multirow{2}{*}{$\begin{array}{c}3 \text { 居住間 } \sigma \\
\text { (関連性 } \\
\left.\chi^{2} \text { 検定 }\right)\end{array}$} \\
\hline & 自 宅 & 寮 & 下 宿 & \\
\hline \multicolumn{5}{|l|}{ 家での食事 } \\
\hline 全然楽しくない & $14(3.3)$ & $8(15.4)$ & $31(24.4)$ & \\
\hline 少し楽しい & $82(19.4)$ & $23(44.2)$ & $54(42.5)$ & $p<0.001$ \\
\hline 楽しい & $126(29.8)$ & $16(30.8)$ & $35(27.6)$ & \\
\hline 非常に楽しい & $22(5.2)$ & $5(9.6)$ & $7(5.5)$ & \\
\hline \multicolumn{5}{|l|}{ 学校は } \\
\hline 不愉快 & $12(4.8)$ & $4(7.5)$ & $2(1.5)$ & \\
\hline 少し不愉快 & $31(12.4)$ & $7(13.2)$ & $14(10.8)$ & \\
\hline 普通 & $102(40.8)$ & $21(39.6)$ & $61(46.9)$ & ns \\
\hline 楽しい & $92(36.8)$ & $18(34.0)$ & $47(36.2)$ & \\
\hline 大変楽しい & $13(5.2)$ & $3(5.7)$ & $6(4.6)$ & \\
\hline \multicolumn{5}{|l|}{ 家に帰ると } \\
\hline 不愉快 & $3(1.2)$ & $3(5.7)$ & $3(2.3)$ & \\
\hline 少し不愉快 & $15(6.0)$ & $5(9.4)$ & $12(9.2)$ & \\
\hline 普通 & $115(46.0)$ & $30(56.6)$ & $75(57.3)$ & $p<0.05$ \\
\hline 楽しい & $91(36.4)$ & $12(22.6)$ & $33(25.2)$ & \\
\hline 大変楽しい & $26(10.4)$ & $3(5.7)$ & $8(6.1)$ & \\
\hline \multicolumn{5}{|l|}{ 毎日の気分 } \\
\hline 瓇鬱 & $14(5.6)$ & $5(9.4)$ & $8(6.2)$ & \\
\hline 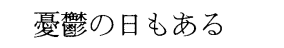 & $130(52.0)$ & $30(56.6)$ & $57(43.8)$ & \\
\hline 普通 & $81(32.4)$ & $10(18.9)$ & $57(43.8)$ & $p<0.05$ \\
\hline 爽快 & $23(9.2)$ & $5(9.4)$ & $6(4.6)$ & \\
\hline 非常に爽快 & $2(0.8)$ & $3(5.7)$ & $2(1.5)$ & \\
\hline \multicolumn{5}{|l|}{ 現在の健康状態 } \\
\hline 非常に疲れている & $34(13.5)$ & $18(34.0)$ & $16(12.2)$ & \\
\hline やや疲れている & $149(59.4)$ & $18(34.0)$ & $64(48.9)$ & \\
\hline 普通 & $53(21.1)$ & $13(24.5)$ & $36(27.5)$ & $p<0.01$ \\
\hline 快調 & $13(5.2)$ & $4(7.5)$ & $12(9.2)$ & \\
\hline 非常に快調である & $2(0.8)$ & $0(0.0)$ & $3(2.3)$ & \\
\hline
\end{tabular}

事を楽しまない傾向がみられたものと推察される。

学校が “大変楽しい”, “楽しい”の合わせた合計は自 宅生 $42 \%$, 寮生 $40 \%$, 下宿生 $41 \%$ で “普通” と意識する ものは自宅生 $41 \%$, 寮生 $40 \%$, 下宿生 $47 \%$ であった。

家に帰った時の気分は，自宅生の方が “普通” (46\%), “楽しい” $(36 \%)$, “大変楽しい” $(10 \%)$ の割合が高く, 寮生は “少し不愉快” (9\%), “不愉快”（6\%）の回答 が自宅生より多く, 有意差が認められた（ 3 居住間 $p<$ 0.05 , 自宅と寮間 $p<0.05)$ 。

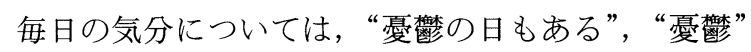
を合わせると, 自宅生 (58\%) と寮生（66\%）に多く, 下宿生（50\%）に少なく, “普通” と回答した割合は, 自宅生 (32\%) や寮生（19\%）よりも, 下宿生（44\%） に多く差異が認められた（3 居住間 $p<0.05$, 自宅と寮 間 $p<0.05$, 寮と下宿間 $p<0.05)$ 。

現在の健康状態について, “非常に疲れている”が自 宅生 $14 \%$, 寮生 $34 \%$, 下宿生 $12 \%$ と寮生に高く, “やゃ 疲れている” は自宅生 $59 \%$, 寮生 $34 \%$, 下宿生 $49 \%$ と自 
宅生に高く差異が認められた（3 居住間 $p<0.01$, 自宅 と寮間 $p<0.01$, 寮と下宿間 $p<0.05)$ 。疲労の原因の 1 つである家事労働は省力化や社会化が進んで軽減された けれども, 家庭内での精神的緊張は増したといわれてい る14)。職場や学校でのストレスの増加, 遠距離通学や交 通機関の混雑, 生活の高速化, 環境污染など, 疲労促進 要因の増加が指摘されており, 学校·地域・家庭の在り 方と関連が深い。大学周辺に 1 人住まいをしている下宿 生に比べ, 自宅生, 寮生には, 遠距離通学するものが多 く, 特に寮生の場合, 寮に帰ると他人との関係で気配り

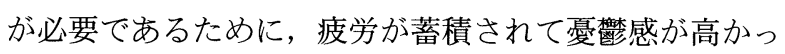

たものと推察される。疲労の予防には, 適切な環境, ス トレスの軽減（円滑な人間関係の確立）等, 生活の在り 方に関わる問題解決が重要であることが示唆された。

\section{2. 居住形態別による食品の摂取頻度との関連性}

調査項目は, たんぱく質や脂肪を多く含む食品として 豆類 (豆腐 - 納豆等を含む), 魚介類, 卵類, 肉類, 植 物油, バターの 6 項目, ビタミンやミネラル, 食物繊維 を多く含む食品と嗜好的食品として緑黄色野菜, 淡色野 菜, 果物類, 乳類 (牛乳, チーズ等), 海藻, 菓子類, 缶コーヒー, 缶ジュース等の甘い飲料の 7 項目, 食べる 頻度は, “1 日 2 回以上”, “毎日 1 回”, “週に $2 \sim 3$ 回”,

“週に 1 回以下”, “ほとんぞ食べない” についてそれぞれ回答してもらった。食 べる頻度の分類は以上の 5 項目とし居住 形態別にその結果を表 4-1, 表 4-2 に 示した。

（1）たんぱく質や脂肪含有食品の摂取 状況の比較 たんぱく質・脂肪含有食 品の摄取状況を表 4-1に示す。

豆類の摂取頻度について, “1 日 2 回 以上”之“毎日 1 回”食べると答えた合 計は, 自宅生が最も多く35\%, 次いで寮 生 $29 \%$ ，下宿生 $25 \%$ であった。“ほとん ど食べない”は, 自宅生 $2 \%$, 寮生 $4 \%$, 下宿生 $11 \%$ で “週に 2 〜 回” が自宅生 $51 \%$, 寮生 $52 \%$, 下宿生 $43 \%$ で，3 居住 間に有意差が見られ, 豆類の摂取は自宅 生に高かった（3 居住間 $p<0.01$, 自宅 と下宿間 $p<0.001)$ 。

魚介類の摂取頻度について“1日 2 回 以上”と“毎日 1 回以上”食べると答え た合計は, 自宅生が最も多く $14 \%$, 次い で寮生 $6 \%$, 下宿生 $1 \%$ であった。“注 とんど食べない”は, 自宅生 $3 \%$, 寮生 13\%, 下宿生 $35 \%$ で “週に $2 \sim 3$ 回”が 自宅生 $69 \%$, 寮生 $60 \%$, 下宿生 $31 \%$ で, 3 居住間に有意差がみられ, 魚介類の摂 取は自宅生に高かった（3 居住間 $p<0$. 001 , 自宅と寮間 $p<0.001$, 自宅と下宿 間 $p<0.001$, 寮と下宿間 $p<0.001)$ 。

卵の摂取頻度について“1 日 2 回以上” と“毎日 1 回”食べると答えた合計は, 自宅生が最も多く $57 \%$, 次いで寮生 $54 \%$, 下宿生 $37 \%$ と少なく, “週に $2 \sim 3$ 回” が自宅生 $36 \%$, 寮生 $40 \%$, 下宿生 $47 \%$ で, 3 居住間に有意差がみられ, 卵類の摂取 は自宅生に高かった（3居住間 $p<0.01$, 自宅と下宿間 $p<0.001)$ 。

肉類の摂取頻度は, “週 $2 \sim 3$ 回” 食 べるものが自宅 $48 \%$, 寮生 $52 \%$, 下宿生 
61\%と最も多く，次いで“毎日 1 回”食べるがそれぞれ $40 \% ， 33 \% ， 24 \%$ で，3 居住間に有意差が認められ，肉 類の摂取は自宅生に高かった（3 居住間 $p<0.001$, 自 宅と下宿間 $p<0.001)$ 。

植物油の摄取頻度について, “1 日 2 回以上”之“毎 日 1 回”食べると答えた合計は，自宅生 $70 \%$, 寮生が76
\%と高く，下宿生は $52 \%$ であった。“週に $2 \sim 3$ 回”が 自宅生と寮生それぞれ $23 \%$, 下宿生が $31 \%$ で， 3 居住間 に有意差がみられ，植物油の摂取は寮生に高かった（3 居住間 $p<0.001$, 自宅と下宿間 $p<0.001$, 寮と下宿間 $p<0.001)$ 。

バターの摂取頻度について，“ほとんど食べない”は， 自宅生と寮生各々 $30 \%$ であり, 下宿生が $53 \%$ と高く“週に $2 \sim 3$ 回”が自宅生 33 $\%$ ，寮生 $32 \% ，$ 下宿生 $15 \%$ で，3 居住間 に有意差が見られ, バタ一の摂取は, 自 宅生・寮生に高かった（ 3 居住間 $p<$ 0.001 , 自宅と下宿間 $p<0.001$, 寮と下 宿間 $p<0.05)$ 。

（2）ビタミン・ミネラル・食物繊維含 有食品と嗜好的食品の摄取状況の比較

ビタミン・ミネラル・食物繊維含有食 品と嗜好的食品の摄取状況を表 4-2に 示す。

緑黄色野菜の摂取頻度について, “1 日 2 回以上”之“毎日 1 回” 食べると答 えた合計は, 自宅生 $63 \%$, 寮生 $64 \%$ に高 く，下宿生は $41 \%$ と低かった。“週に 2 ～ 3 回” 食べるが自宅生 $34 \%$, 寮生 $26 \%$ で下宿生 $47 \%$ と多く，3 居住間に有意差 がみられ，緑黄色野菜の摂取は自宅生と 寮生に高かった（3 居住間 $p<0.001$, 自宅と下宿間 $p<0.001)$ 。

淡色野菜の摂取頻度について，“1 日 2 回以上”之“毎日 1 回”食べると答え た合計は，自宅生が $68 \%$ と高く，次いで 寮生は $62 \%$ であり，下宿生は $44 \%$ と低か った。“週に $2 \sim 3$ 回” 食べるが自宅生 $30 \%$, 寮生 $31 \%$ で下宿生 $44 \%$ と多く, 居 住間に有意差がみられ, 淡色野菜の摂取 は自宅生に高かった（3居住間 $p<$ 0.001 , 自宅と下宿間 $p<0.001)$ 。

果物の摂取頻度について，“1 日 2 回 以上”と“毎日 1 回”食べると答えた合 計は, 自宅生が $43 \%$ と高く, 次いで寮生 は36\%であり，下宿生は14\%と低かった。 “ほとんど食べない”は，それぞれ $5 \%$ ， $8 \%$ で下宿生 $18 \%$ に多く“週に $2 \sim 3$ 回” が自宅生 $38 \%$, 寮生 $43 \%$, 下宿生 $37 \%$ と 差異がみられ，果物の摂取は自宅生に高 かった（3 居住間 $p<0.001$ ，自宅と下 宿間 $p<0.001$ ，寮と下宿間 $p<0.001)$ 。

乳類の摂取頻度について, “1 日 2 回 以上”之“毎日 1 回”食べると答えた合 計は，自宅生63\%，寮生59\%，下宿生は 51\%であった。 
[論文〕居住形態からみた女子大生の健康と食生活との意識調査

海藻の摂取については “週に $2 \sim 3$ 回”食べるものが 多く, 自宅生は $51 \%$, 寮生 $46 \%$, 下宿生が $31 \%$ で “ほ んど食べない”は，それぞれ $4 \% ， 6 \%$ で宿生は30\% と多く差異が認められた（3 居住間 $p<0.001$, 自宅と 寮間 $p<0.05$, 自宅と下宿間 $p<0.001$, 寮と下宿間 $p<$ $0.01)$ 。

菓子類の摂取頻度について，“1 日 2 回以上”と“毎 日 1 回”食べると答えた合計は, 自宅生が $45 \%$, 寮生 46 \%であり，下宿生は $26 \%$ と低かった。“ほとんど食べな い”は，自宅生 $8 \%$, 寮生 $6 \%$ で下宿生が $15 \%$ と高かっ た。 3 居住間に有意差が見られ，菓子の摂取は自宅生と 寮生に高かった（ 3 居住間 $p<0.01$, 自宅と下宿間 $p<0$. 001 ，寮と下宿間 $p<0.05)$ 。

缶コーヒー, 缶ジュース等の甘い飲料の摄取頻度につ いて, “1 日 2 回以上”と“毎日 1 回”飲むと答えた合 計は，自宅生が $16 \%$ ，寮生 $21 \%$ であり，下宿生は $10 \%$ と 少なかった。“ほとんど飲まない”は，自宅生30\%，寮 生 $28 \%$ で下宿生 $37 \%$ と多く“週に 2 〜 回” 飲むものは, 自宅生 $38 \%$, 寮生 $23 \%$, 下宿 $33 \%$ であり 3 居住間に差が みられた（ 3 居住間 $p<0.05$ ，寮と下宿間 $p<0.05 ） 。$

\section{(3) 多変量解析の因子分析}

1）解析方法: 食品摂取状況から, 食生活の良否を 推測する可能性を探るため, 女子学生の食品摂取頻度を 「自宅」「寮」「下宿」という居住形態からみた栄養バラ ンスや関連性および類似性を因子分析によって意味づけ を行った。

因子分析は，食品名を変数として，摂取頻度である 1 日 2 回以上を 5 , 毎日 1 回を 4 , 週に $2 \sim 3$ 回を 3 , 週 に 1 回以上を 2 ，食べないを 1 とした数值のカテゴリー 化を行い，パネラー数を観測回数としてデータ表を作成 し実施した。

因子分析では，はじめに共通性の推定について相関係 数の最大を初期值とした。因子の数は, 因子の重要度を 示すと考えられる 1.00 以上の固有值が第 2 因子までであ ったことや寄与率が第 2 因子から少なくなっていること から，2つに設定することにした。次に，得られた因子 負荷量を散布図（図 1 ）によって，説明変数のポシショョ ニングを行い，変数の関連性や類似性を明らかにするこ とにした。因子負荷量から因子を解釈すると, 第 1 因子 はグラフX軸で右側の分布に「食べる」という肯定的回 答である因子の意味づけが推察される。第 2 因子では, 説明変数のウエイトを示す因子負荷量が小さかったので 意味づけができなかった。

2) 因子分析 : 居住形態別について比較すると, 自 宅生では，第 2 因子までの累積寄与率は $31.2 \%$ となり, 因子負荷量は第 1 因子では淡色野菜 0.72 と緑黄色野菜 0.68 の因子負荷量が大きかった。図 1 に両因子の負荷量 を示したが，第 1 因子の因子負荷量を示すX軸の右側に 淡色野菜と緑黄色野菜が位置している特徵がみられた。 また自宅生のグラフはX軸の0.4以上にほとんどの食品

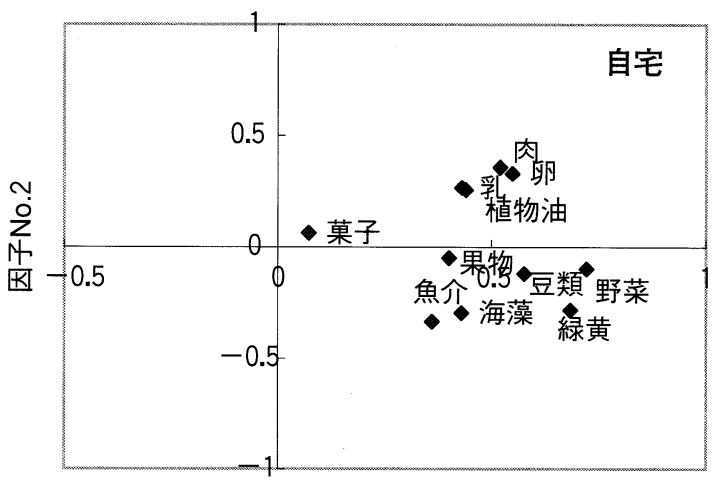

因子No.1

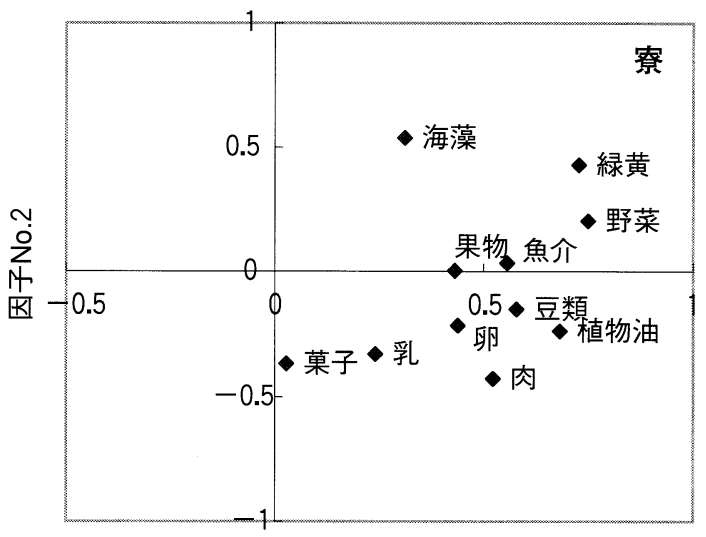

因子No.1

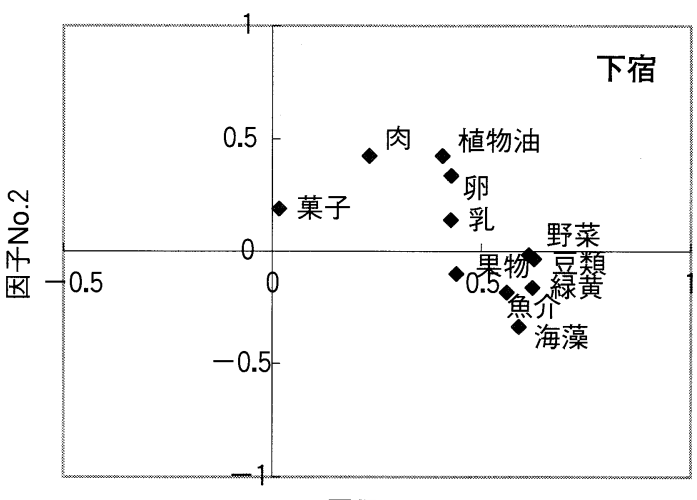

因子No.1

図 1 因子負荷量の散布図

群が分布する集中型で，第 1 因子をより多く備えている と判断でき，主要な食品群の摂取頻度に偏りが少ないこ とが示唆された。

寮生では，第 2 因子までの累積寄与率は $37.0 \%$ となり， 因子負荷量は第 1 因子では淡色野菜が 0.75 , 緑黄色野菜 が 0.73 ，植物油が 0.68 と負荷量が大きかった。両因子の 負荷量を図 1 に示したが，第 1 因子を示すX軸の右側 0.6 以上に淡色野菜, 緑黄色野菜, 植物油が位置してい る特徵がみられた。一方, 第 2 因子のY軸の 0.5 付近に海 藻が，一0.4付近に肉類が位置していた。寮生は, 野菜 と植物油の同時摂取, 例えば野菜炒めなどの頻度が高く, 海藻摂取頻度が高いと肉類の志向が低いことが示唆され， 
摂取する食品の分布が広く，広範囲型と なっていた。

下宿生では, 第 2 因子までの, 累積寄 与率は $30.1 \%$ であった。因子負荷量 0.6 以上とすると豆類が 0.63 , 緑黄色野菜が 0.62 , 淡色野菜が 0.61 と負荷量が多かっ た。両因子の負荷量を図 1 に示したが, 第 1 因子を示す X軸の右側 0.5 以上に豆 類, 緑黄色野菜, 淡色野菜, 海藻, 魚介 類が位置していた。一方, 第 2 因子につ いては, Y軸の 0.4 付近に植物油, 肉類 が位置していた。このことから下宿生は 野菜や豆の志向が強く, 植物油と肉類の 同時拱取, 例えば肉炒めなどの摄取パ ターンが示唆された。これらの結果から, 女子学生の食品摂取頻度加少た食品群 間の関連性や類似性の意味づけができた。 緑黄色野菜, 淡色野菜々いう「野菜志向」 の類似性が挙げられるが，居住形態別に 比べると, 拱取形態として寮生は植物油 と野菜を同時に摂取し, 下宿生は植物油 と肉類を同時に摂取するという特徵があ った。一般的には動物, 植物, 魚類由来 の脂肪酸をバランスよく摂取することが 大切である。特に魚介類に多い $\alpha$-リノ

表 5 サプリメントの摂取状況の比較 $\%$

\begin{tabular}{|c|c|c|c|}
\hline \multirow{2}{*}{ 調 查 項 目 } & \multicolumn{2}{|c|}{ 下宿生（1人暮らし） } & \multirow[b]{2}{*}{$\chi^{2}$ 検定 } \\
\hline & 欠食習慣なし & 欠食習慣あり & \\
\hline \multicolumn{4}{|l|}{ サプリメントの意識 } \\
\hline 不足する栄養素のみ摂取 & 66.7 & 57.7 & \multirow{5}{*}{ ns } \\
\hline 摂取すべきでない & 18.3 & 25.4 & \\
\hline 自分の考えにあてはまるものなし & 6.7 & 8.5 & \\
\hline パフォーマンスの向上に役立つ & 6.7 & 7.0 & \\
\hline 積極的に摂取 & 1.6 & 1.4 & \\
\hline \multicolumn{3}{|l|}{ サプリメントの情報 } & \multirow{5}{*}{$p<0.05$} \\
\hline 十分得られている & 20.0 & 8.5 & \\
\hline あまり得られていない & 40.0 & 64.8 & \\
\hline 全く得られていない & 8.3 & 4.2 & \\
\hline どちらともいえない & 31.7 & 22.5 & \\
\hline \multicolumn{4}{|l|}{ 摂取状況 } \\
\hline 現在攝取している & 33.3 & 22.5 & \multirow{3}{*}{$\mathrm{ns}$} \\
\hline 過去に摂取していた & 36.7 & 40.9 & \\
\hline 摂取したことがない & 30.0 & 36.6 & \\
\hline \multicolumn{4}{|l|}{ 初めて利用した時期 } \\
\hline 小学生 & 11.7 & 12.7 & \multirow{5}{*}{ ns } \\
\hline 中学生 & 26.7 & 21.1 & \\
\hline 高校生 & 38.3 & 40.8 & \\
\hline 大学生 & 21.7 & 25.3 & \\
\hline その他 & 1.6 & 0.0 & \\
\hline
\end{tabular}

「欠食習慣あり」は「時々欠食する」と「よく久食する」の合計。

\section{レン酸系列の EPA や DHA などの n-3}

系多価不飽和脂肪酸と, 植物油に多いリノール酸系列の 比率として $1 ： 4$ が適切な摂取として提唱されている。 植物油などの多価不飽和脂肪酸は健康の維持には必要で あるが，過㮃摂取には配慮する必要があり，下宿生と寮 生の脂肪酸摂取比率も今後の検討課題であると推察され る。

(4) サプリメントの摂取状況の比較 サプリメント について, “意識”, “情報”, “摂取状況” “摂取した時期” の 4 項目を回答してもらった。サプリメントに関する 4 項目について 3 居住間で比較したところ差異は認められ なかったので, 食品摂取頻度が最低であった下宿生につ いて, 久食習慣なし者と欠食習慣あり者の 2 群に分けて 比較し，表 5 に示した。

欠食習慣有無別とサプリメントに関する意識との関連 性をみると, 差異は認められなかったが, “不足する栄 養素のみ摄取” は, 欠食習慣なし者 $(67 \%)$ が, 欠食習 慣あり者 $(58 \%)$ より多い傾向がみられた。

欠食習慣とサプリメントに関する情報との関連性をみ ると, “あまり得られていない”, “全く得られていない” を合わせた合計は，欠食習慣なし者 $(48 \%)$ より欠食習 慣あり者 $(69 \%)$ に高く, “十分得られている” は食 習慣なし者 $(20 \%)$ より欠食習慣あり者（9\%) に低く， 差異が認められた $(p<0.05)$ 。

欠食習慣とサプリメントの摂取状況について差異は認
められなかったが，“現在摂取している”で欠食習慣な し者（33\%）のほうが欠食習慣あり者（23\%）より高い 傾向がみられた。下宿生で欠食習慣のあるものは, サプ リメントの情報源も少なく, 栄養素の補助としてサプリ メントを利用しない傾向が推察された。

初めてサプリメントを摂取した時期は, “小学生” “中 学生” 合わせると, 欠食習慣なし者が $38 \%$ で久食習慣あ り者が $34 \%$ と, いずれも早期から摂取していることが同 える。青年期は生涯の食習慣形成に最も影響が大きいの で, 摂取には注意が必要なこと年)16)や，この時期の栄養 補助食品の使用次第では将来のサプリメント依存につな がることが懸念されている17)。さらに青年期の栄養教育 が不十分18)であることも報告されており，サプリメント についての教育が必要であることが示唆された。

以上の結果から, 自宅通学生と比較して, 下宿で生活 する学生には食生活と健康に関する問題点があった。自 宅生は, 下宿生に比べて, 多様な食品を摄取しており, 健康に配慮されたバランスのとれた食習慣を意識してい ることが伺えた。また自宅生の“便秘傾向”の割合は下 宿生より低い傾向を示していた。その理由は, 自宅生が 家族とともに「共食」することで, 健全な食生活設計の 基本でもある米を主食として位置づけ, 国民栄養調査の 食品相関行列にみる11d), 米と正の相関の高い食品であ る豆類 (豆腐·納豆等を含む), 海藻, 野菜等, 特に食 
〔論文〕居住形態からみた女子大生の健康と食生活との意識調査

物繊維を多く含む食品をバランスよく摂取している点に あると推察される。他方，下宿生は「孤食」のため比較 的限られた食品しか摂取せず，また摂取頻度も低いとい う有意差が認められ, 特にたんぱく質, 食物繊維, ビタ ミン，ミネラルを多く含む食品を少量しか摂取していな ことが示唆された。食物繊維摂取量不足は便秘傾向が, たんぱく質，ミネラル，ビタミン不足は貧血者増加への 危険率が，それぞれ高いことを示唆している。特に下宿 生に対しては，“自分の健康は自分でつくる”という自 主的な健康管理の精神に基づいて，日常的にバランスの よい食事を維持できるような食事指導および食教育が望 まれる。

\section{要 約}

女子大学生の居住形態加らた健康と食生活に関連し た意識を検討するために，北海道札幌市周辺の女子学生 435 人についてアンケート調査を行った。

1 ）健康を保つのに適した食生活を“している”, “大体している”と答えた合計は自宅生と寮生各々 $46 \%$ と多く，下宿生は $28 \%$ であった。健康な食生活を“して いない”は自宅生 $20 \%$ ，寮生 $25 \%$ に対して，下宿生は44 $\%$ と多く, 3 居住間に有意な差が認められ, 健康に適し た食生活の意識は自宅生と寮生で高かった（ 3 居住間 $p$ $<0.001$, 自宅と下宿間 $p<0.001$, 寮と下宿間 $p<0.001)$ 。

2）家での食事について，居住形態別に比較すると, “少し楽しい”, “楽しい”“非常に楽しい”を合わせた合 計は，自宅生 $97 \%$ ，寮生85\%で，両者共に食事を楽しん でおり，逆に“楽しんでいない”は，寮生15\%より下宿 生 $24 \%$ の方に多く，食事を楽しんでいない学生は下宿生 に多いことが認められた（ 3 居住間 $p<0.001$, 自宅と 寮間 $p<0.05$, 自宅と下宿間 $p<0.001)$ 。

3 ）食品摂取頻度は自宅生が相対的に高く，次は寮 生が続き，下宿生は最低であった。自宅生に比べて，寮 生に摂取頻度が低かった食品は魚介類と海藻類であり， 有意差が認められた（各々 $p<0.001$ と $p<0.05 ） 。$

4 ）学生の欠食状況は“よく欠食する”之“時々欠 食する”を合わせた合計は，自宅生32\%，寮生43\%の順 で，下宿生は $54 \%$ と多く，“欠食しない” は，自宅生 68 \%, 寮生 $57 \%$ の順で，下宿生は $46 \%$ と少なく，下宿生で 欠食頻度が最も高い傾向がみられた（ 3 居住間 $p<$ 0.001 ，自宅と下宿間 $p<0.001)$ 。

\section{文献}

1）石毛直道編：人間·たべもの·文化，平凡社，pp.12-13， 230-231（1980）

2）厚生省保健医療局健康増進栄養課監修：健康づくりのた めの食生活指針（対象特性別），第一出版（1990）

3）岸田典子，上村芳枝：学童の食事中に打ける会話の有無 と健康及び食生活との関連, 栄養学雑誌，51，23-30（1993）

4）江上いすず，長谷川昇，大矢みどり：女子学生の食行動 之性格特性からみた肥満の成因，栄養学雑誌，53，191-198 (1995)

5）中嶋洋子：女子学生の体組織とエネルギーバランス及び 食生活状況の関連について, 栄養学雑誌, 52, 227-235 (1994)

6）木村友子，加賀谷反え子，福谷洋子：女子大学生とその 母親の生活行動並びに食生活状況の実態調査, 栄養学雑誌, 50, 325-336 (1992)

7）岡本佳子, 藤本重子 : 下宿大学生の食生活と健康に関す る意識調査, 栄養学雑誌, 48, 63-71 (1990)

8）伊海公子, 坂本裕子, 三好正満 : 下宿女子学生の生活環 境と食生活型，栄養学雑誌，55，239-251（1997）

9）平井和子，武副礼子，尾関百合子，宮川久邇子：男子大 学生の食生活と健康に関する意識, 栄養学雑誌, 51，81-89 (1993)

10）厚生労働省健康局総務課生活習慣病対策室栄養調査係編： 平成13年国民栄養調査結果の概要抜粋，栄養学雑誌 61 , 55-62 (2003)

11）日本栄養士会：健康日本 21 と栄養士活動, 第一出版, 11a) $20,11 \mathrm{~b}) 67-69,11 \mathrm{c}) 23$, 11d) 207 (2000)

12）東川赾美，古崎和代，菊地和美，䓟田雅子，平井和子： 女子学生とその母親の欠食状況と健康との関係, 日本食生 活学会誌，14，31-39（2003）

13）北海道新聞 4 月 10 日 $\cdot 17$ 日私大助成推進協議会調査 (2003)

14）日本家庭科教育学会編：家庭科教育事典, 実教出版, 172 (1992)

15) Branen, L. and Fletcher, J.: Comparison of College Students' Current Eating Habits and Recollections of their Childhood Food Practice, Journal of Nutrition Education, 31 (6), 304-310 (1999)

16）川野 因：適切な使用方法についての指導規則, 臨床ス ポーツ医学，19(10)，1127〜1134（2002）

17）樋口 満：食生活をきちんとすれば必要な栄養は摂れる, Sportsmedicine, 8 ( 2) ) 41 44 (1996)

18) Sugiura, K., Suzuki, I. and Kobayashi, K.: Nutritional Intake of Elite Japanese Track-and-Field Athletes, International Journal of Sport Nutrition, 9 , 202-212 (1999) 